\title{
Gangguan Kognitif pada Anemia Defisiensi Besi
}

\author{
Lily Irsa
}

\begin{abstract}
Anemia defisiensi besi masih merupakan masalah kesehatan terutama di negara yang sedang berkembang. Zat besi banyak dibutuhkan otak karena metabolisme oksidasinya yang tinggi. Beberapa enzim dalam proses oksidasi dan metabolisme sel membutuhkan besi. Gangguan kognitif pada anemia defisiensi besi telah banyak diteliti. Beberapa hal yang berhubungan dengan gangguan kognitif pada anemia defisiensi telah dikemukakan; terganggunya enzim-enzim yang berperan dalam metabolisme otak, gangguan dalam mielinisasi dan terganggunya oksigenasi sel. Pada pemeriksaan terhadap bayi yang menderita anemia defisiensi besi didapatkan skor Mental Development Index (MDI) yang rendah dan Infant Behavior Record (IBR) memperlihatkan perbedaan emosi. Pada anak usia sekolah didapatkan prestasi belajar yang rendah dan konsentrasi belajar yang singkat.
\end{abstract}

Kata kunci: anemia defisiensi besi, gangguan kognitif

D efisiensi besi merupakan penyebab utama anemia di seluruh dunia. ${ }^{1,2}$ Diperkirakan $30 \%$ penduduk dunia menderita anemia dan lebih kurang 500-600 juta menderita anemia defisiensi besi. ${ }^{1}$ Prevalensi yang tinggi terjadi di negara yang sedang berkembang. ${ }^{2,3}$ Di Amerika Serikat anemia defisiensi besi terdapat pada $25 \%$ bayi dan $6 \%$ anak. $^{4}$ Di Asia Tenggara prevalensi pada kelompok prasekolah dan wanita hamil diperkirakan antara 50\% dan 70\%. ${ }^{5}$ Anemia defisiensi besi terjadi bila asupan besi ke dalam eritroid di sumsum tulang sangat terganggu menyebabkan konsentrasi hemoglobin menurun. Keadaan ini menyebabkan sel eritrosit mikrositosis dan hipokromia secara progresif. ${ }^{1}$

Komponen yang mengandung besi di dalam tubuh di bedakan dalam 2 kelompok yaitu 2,6

- Senyawa besi-heme seperti hemoglobin, sitokrom, mioglobin, katalase dan peroksidase.

- Protein besi-sulfur dan metalloflavoprotein seperti nikotinamida adenin dinukleotida tereduksi (NADH) dehidrogenase, suksinik dehidrogenase

\footnotetext{
Alamat korespondensi:

Dr. Lily Irsa, Sp.A.

Bagian Ilmu Kesehatan Anak. FK-USU/RS H Adam Malik, Medan.

Jl. Bunga Lau no. 17, Medan 20136.

Telepon: 061-836 0405, 836 0143. Fax.: 061-836 1721.
}

dan xantin oksidase.

Tujuh puluh persen dari besi di dalam tubuh adalah dalam bentuk hemoglobin, sebagian besar sisanya terdiri dari feritin dan hemosiderin. Sebagian kecil dalam bentuk mioglobin dan enzim-enzim. ${ }^{2,6,7}$ Kebutuhan besi yang direkomendasikan oleh Committee on Nutrition of the American Academy of Pediatric adalah $1 \mathrm{mg} / \mathrm{kg} \mathrm{BB} /$ hari untuk bayi cukup bulan, $2 \mathrm{mg} / \mathrm{kg} \mathrm{BB} /$ hari dan 10 $\mathrm{mg} /$ hari untuk anak berumur 4-10 tahun kemudian meningkat $18 \mathrm{mg} /$ hari pada umur 11 tahun ke atas. ${ }^{6}$

Defisiensi besi hingga menimbulkan anemia terjadi secara bertahap, ${ }^{8,9}$

1. Pengosongan cadangan besi, feritin dan hemosiderin dari sumsum tulang dan penurunan konsentrasi feritin serum.

2. Menurunnya konsentrasi besi serum dan bersamaan dengan meningkatnya total iron binding capacity $(T I B C)$ dan transferin.

3. Peningkatan konsentrasi sel eritrosit porfirin, menurunnya saturasi transferin serum dan digambarkan dengan menurunnya mean corpuscular rate (MCV).

4. Menurunnya konsentrasi hemoglobin.

Faktor yang sering menyebabkan defisiensi besi pada anak adalah pertumbuhan yang cepat, sedikitnya asupan besi dan perdarahan kronis, pada beberapa kasus disebabkan oleh kombinasi dari faktor di atas. ${ }^{6,10}$ 
Permasalahan yang timbul akibat defisiensi besi selain anemia secara substansial dihubungkan dengan perubahan non hematologi akibat kurangnya zat besi di jaringan. Gejala karena anemia berupa pucat, lesu, cengeng, anoreksia, aktifitas menurun, sesak nafas sampai terjadi gagal jantung pada anemia yang berat. ${ }^{1,10,11}$ Gejala karena kurangnya zat besi di jaringan seperti pika, ${ }^{1,2,11}$ perubahan pada epitel, ${ }^{1,2,12-14}$ gangguan fungsi imunitas, ${ }^{1,7}$ gangguan fungsi pengaturan suhu, ${ }^{1,14}$ gangguan pertumbuhan, ${ }^{5}$ serta gangguan perkembangan kognitif dan tingkah laku. ${ }^{1,5,15}$

Tulisan ini bertujuan untuk menjelaskan timbulnya gangguan kognitif pada anemia defisiensi besi.

\section{Zat Besi di Dalam Otak}

Besi adalah nutrien yang penting tidak hanya untuk pertumbuhan normal, kesehatan dan kelangsungan hidup anak, tetapi juga untuk perkembangan mental, motorik dan fungsi kognitif. ${ }^{16}$ Otak membutuhkan zat besi yang banyak karena metabolisme oksidasinya yang tinggi dibandingkan dengan organ lain. Kurangnya kadar besi pada masa pasca natal mengakibatkan gangguan mental dan motorik yang akan menetap sampai dewasa. Jadi, besi harus ditransfer ke sel-sel otak dengan pengaturan yang baik. Transferin merupakan protein yang mentranspor besi ke otak dan dapat melewati sawar darah otak. ${ }^{17}$

Di dalam otak, besi berpartisipasi dalam aktivitas enzimatik termasuk sistim sitokrom oksidase, menurunkan nicotinamide adenin dinucleaeotide phosphate (NADPH) reductase dan ribonucleotide reductase yang mengatur pertumbuhan otak, delta-9 desaturase pada mielinasi, tirosin hidroksilase pada sintesis dopamine D2 reseptor dan sitokrom dalam produksi energi. ${ }^{17,18}$ Sebagai suatu komponen integral dari metabolisme oksidatif seluler sel-sel saraf, sitokrom penting untuk fungsi seluler sel saraf yang memperlihatkan cukupnya aktifitas metabolisme sel saraf. ${ }^{18}$ Aktifitas neurologikal yang lebih spesifik, besi terlibat dalam fungsi dan sintesa dopamin, serotonin dan g-amino butyric acid (GABA). ${ }^{17}$ Tikus yang menderita defisiensi besi juga mengalami defisiensi besi pada otaknya, diidentifikasi perubahan biokimia yang mendasarinya adalah kurangnya aktifitas aldehid oksidase dan meningkatnya konsentrasi senyawa serotonin dan 6-hidroksiindole. ${ }^{1}$ Metabolisme katekolamin yang abnormal diduga sebagai faktor yang berhubungan dengan perubahan tingkah laku. Aktifitas monoamin oksidase menurun pada hati tikus yang mengalami defisiensi besi. Monoamine oksidase bertanggung jawab dalam deaminasi norepinefrin, dopamin, 5-hidroksitriptamin, feniletilamin, triptamin dan amine primer serta amine sekunder lainnya yang terdapat pada susunan syaraf pusat (SSP) dan jaringan lain. Kadar norefinefrin meningkat pada urin anak yang mengalami defisiensi besi dan membaik setelah diberikan terapi besi. ${ }^{1,19}$ Besi juga terlibat dalam sintesa serta degradasi asam lemak dan kholesterol; mungkin juga mempunyai peran penting dalam mielogenesis dan pemeliharaan mielin. ${ }^{17}$ Mielin sangat penting untuk kecepatan hantar rangsangan melalui sel-sel saraf. Mielinisasi terjadi dalam beberapa tahap yaitu tahap pranatal dan tahap pasca natal. Sebagian besar proses meilinisasi sudah selesai pada umur 10 tahun. ${ }^{20}$ Penemuan tentang perubahan SSP akibat anemia defisiensi besi pada anak sangat terbatas. Penelitian Roncagliolo, dkk terhadap respon auditory brain stem, didapatkan waktu hantaran sentral memanjang pada anak berumur 6 bulan yang menderita anemia dan setelah anemia dikoreksi tidak terjadi perbaikan. ${ }^{21}$ Penelitian tersebut merupakan spekulasi dari penelitian $\mathrm{Yu}, \mathrm{dkk}$ pada tikus yang menderita defisiensi besi didapatkan gangguan dalam mielinasi. ${ }^{22}$ Anak menderita anemi juga mempunyai visual evoked potentials yang memanjang. ${ }^{23}$

\section{Kelainan Kognitif}

Anemia defisiensi besi berhubungan dengan penampilan yang buruk dalam psikomotor dan skala perkembangan mental dan tingkatan tingkah laku pada bayi, nilai yang rendah dalam uji fungsi kognitif pada anak prasekolah, pada anak usia sekolah nilai uji fungsi kognitif dan uji prestasi belajar juga rendah. ${ }^{16}$ Kelainan kognitif dan tingkah laku merupakan salah satu gejala akibat kekurangan zat besi di jaringan. Keadaan ini merupakan gejala yang sangat mengkhawatirkan, terutama bila terjadi pada masa bayi. ${ }^{13}$ Gejala anemia defisiensi besi tidak disebabkan semata-mata karena menurunnya hemoglobin, akan tetapi dipengaruhi juga oleh perubahan biokimia, seperti menurunnya enzim yang mengikat zat besi, ko-enzim yang mengikat zat besi dalam siklus Krebs yang erat hubungannya dengan proses oksigenisasi sel termasuk sel jaringan otak. ${ }^{24}$ Anemia defisiensi besi menyebabkan banyak hal yang 
Sari Pediatri, Vol. 4, No. 3, Desember 2002

merugikan individu secara jasmaniah, juga besar pengaruhnya terhadap sikap atau tingkah laku individu yang bersangkutan seperti reaksi terhadap sekelilingnya dan mempengaruhi proses belajar anak. Kognitif adalah kemampuan menguasai pengetahuan tentang suatu kenyataan atau teori dan cara menggunakannya. Perilaku merupakan kegiatan organisme yang dapat diamati. ${ }^{24,25}$ Berbagai penemuan mutakhir telah menunjukkan dengan jelas bahwa ada hubungan yang erat antara kegiatan otak, perilaku, dan pengalaman. ${ }^{25}$ Walaupun hubungan antara defisiensi besi dengan perubahan tingkah laku belum dapat disimpulkan dari beberapa penelitian. Secara umum sepakat bahwa anak yang defisiensi besi bersifat cengeng, apatis dan mempunyai kemampuan berkonsentrasi pendek. ${ }^{1}$

Dari beberapa penelitian dapat dilihat anemia defisiensi besi berdasarkan umur.

\section{Anemia defisiensi besi pada umur kurang dari 2 tahun}

Ungria M, dkk. menyatakan bahwa defisiensi besi pada masa perinatal perlu diketahui karena menyebabkan hilangnya aktifitas sitokrom oksidase pada struktur otak tertentu. Hippokampus dan daerah prefrontal terlihat paling mudah dikenai ${ }^{18}$ Walter dkk, melaporkan bahwa anak berumur 15 bulan yang menderita anemia defisiensi besi sedang dengan nilai $\mathrm{Hb}$ antara $8,5 \mathrm{~g} / \mathrm{dL}$ sampai dengan $11 \mathrm{~g} / \mathrm{dL}$ mempunyai Mental Development Index yang rendah tetapi Psychomotor Development index tidak berbeda dengan anak yang tidak anemia. Analisa Infant Behavior Record (IBR) memperlihatkan perbedaan dalam emosi secara umum, bayi yang anemia terlihat tidak ceria. Setelah mendapatkan terapi besi selama ratarata 10 hari menampakkan perbaikan dalam lamanya konsentrasi dan lebih kooperatif serta perkembangan psikososial juga membaik. ${ }^{26}$ Aukett, dkk melaporkan peningkatan berat badan dan perkembangan pada anak berusia 17-18 bulan dengan nilai $\mathrm{Hb} 8-11 \mathrm{~g} / \mathrm{dl}$ setelah diberikan besi dan vitamin $\mathrm{C}$ selama 2 bulan. ${ }^{27}$ Pada penelitian terhadap bayi yang berumur 12-23 bulan, Lozoff, dkk. mendapatkan nilai tes mental yang rendah dan gangguan terhadap afektif. Setelah terapi besi tidak terdapat perbaikan dalam nilai tes mental. ${ }^{28}$ Idjradinata P. dan Pollit E. juga mendapatkan nilai perkembangan mental dan motorik yang rendah pada anak yang anemia defisiensi besi sedang yang berusia 12-18 bulan , tapi berbeda dengan Lozoff, keadaan ini membaik setelah mendapat terapi ferosulfat. ${ }^{29}$

\section{Anemia defisiensi besi pada anak usia sekolah}

Anak usia sekolah yang menderita anemia defisiensi besi mempunyai nilai matematika yang lebih rendah dibandingkan anak yang status besinya normal dan nilai the block design test juga lebih rendah. ${ }^{30}$ Soemantri mendapatkan konsentrasi belajar dan prestasi belajar yang rendah pada anak anemia defisiensi besi dan setelah diberi suplemen besi sehingga nilai hemoglobin $>10,5 \mathrm{~g} / \mathrm{dl}$ terdapat peningkatan skor konsentrasi dan prestasi belajar. ${ }^{24}$ Dalam sebuah penelitian jangka panjang Lozoff dkk. mendapatkan anak yang mengalami anemia defisiensi besi pada masa bayinya dengan nilai hemoglobin $<10 \mathrm{~g} / \mathrm{dl}$, saat berumur 5 tahun dengan status hematologi baik mempunyai nilai uji mental dan fungsi motorik yang rendah. ${ }^{31}$

Dari beberapa penelitian dapat dilihat bahwa anemia pada anak berumur $>2$ tahun mempunyai gangguan kognitif dan prestasi belajar yang rendah. Gangguan kognitif akan membaik setelah diterapi dengan besi, tetapi hasil tes ulang terhadap prestasi belajar tidak membaik. Bila anemia defisiensi besi terjadi saat berumur $<2$ tahun, walaupun sudah diberikan suplemen besi anak tersebut tidak bisa mengejar perkembangan anak yang tidak menderita anemia. $^{23}$

Defisiensi besi pada masa bayi dapat menimbulkan akibat yang bertahan lama. Perubahan dalam emosi, tingkah laku, lama konsentrasi yang pendek dapat menimbulkan gangguan perkembangan kognitif. Anak yang sangat cengeng juga menimbulkan efek terhadap kualitas perhatian orang tua dan interaksi sosial, hal ini menimbulkan risiko terhadap penyimpangan perkembangan anak bertambah. ${ }^{19}$

\section{Kesimpulan}

Anemia defisiensi besi masih merupakan masalah di negara yang sedang berkembang. Prevalensi yang tinggi pada usia 6 bulan -3 tahun, pada saat itu sedang terjadi pertumbuhan yang cepat. Kelainan yang ditimbulkan dan mengkhawatirkan adalah terjadinya gangguan kognitif dan perubahan tingkah laku. Anemia defisiensi besi pada masa bayi menimbulkan perubahan tingkah laku dan lama berkonsentrasi yang pendek yang dapat menimbulkan gangguan perkembangan kognitif. Keadaan ini tidak membaik setelah terapi besi terutama 


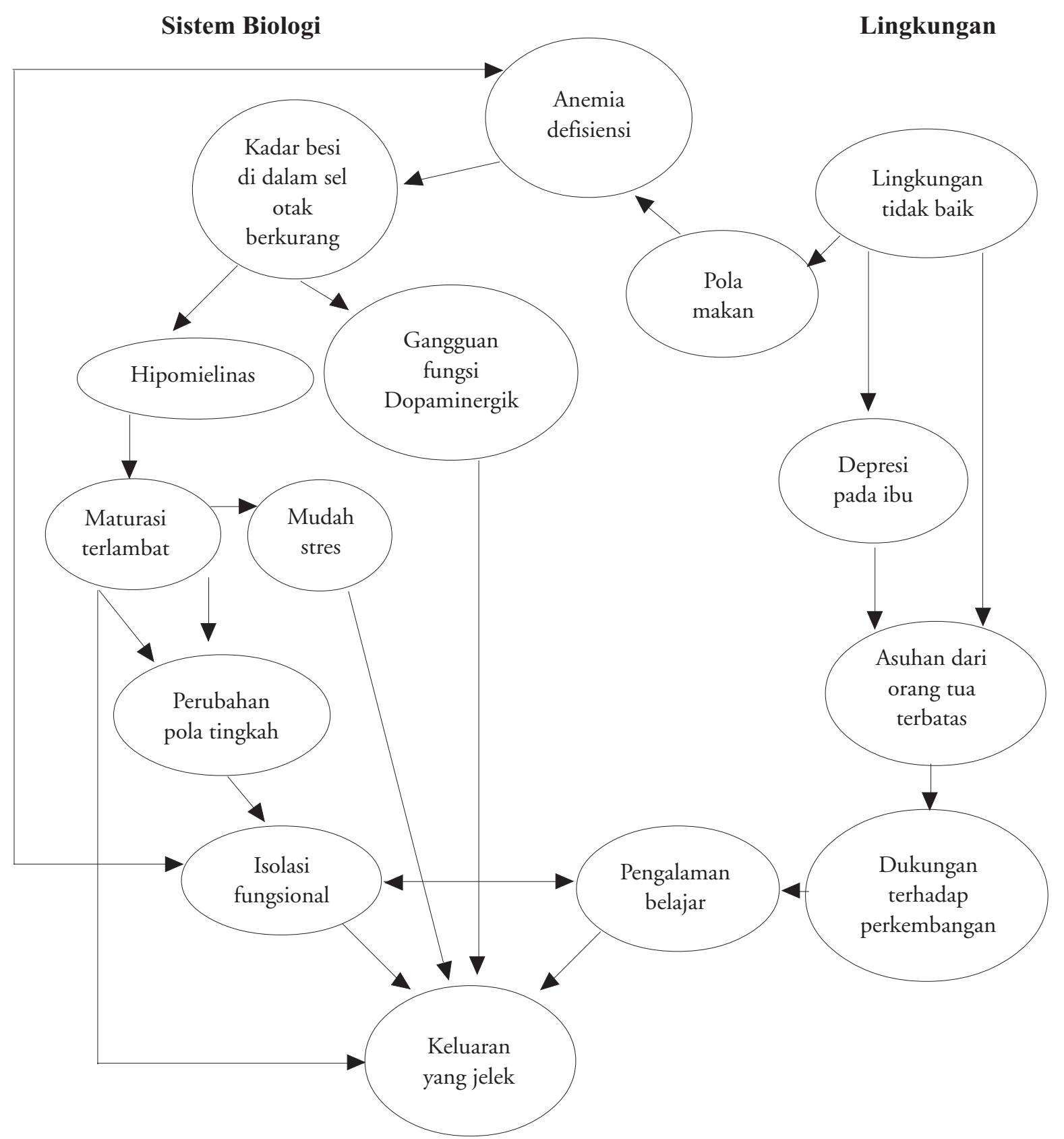

Bagan Pengaruh anemia defisiensi besi terhadap perkembangan ${ }^{32}$

bila defisiensi besi terjadi pada usia $<2$ tahun. Bagan di atas menyimpulkan bahwa anemia defisiensi besi menyebabkan defisiensi besi di otak yang menimbulkan hipomielinasi dan gangguan fungsi dopaminergik sehingga mudah stres, hal ini menimbulkan perubahan tingkah laku dan menyebabkan gangguan proses belajar. Perhatian orang tua yang kurang dalam mendukung perkembangan juga berpengaruh dalam menimbulkan gangguan kognitif.

\section{Daftar Pustaka}

1. Lukens JN. Iron metabolism and iron deficiency. Dalam: Miller DR, Bachner RL, Miller LP, penyunting. Blood diseases of infancy and childhood. Edisi ketujuh. Toronto: Mosby, 1995. h. 193-219.

2. Wintrobe MM dkk,. Clinical hematology. Edisi kedelapan. Washington: Lea \& Febiger,1981. h. 617-41.

3. Hanifi S, Unsal O, Mustafa B, Pukrii A, Soner S. Iron deficiency and iron deficiency anemia in infant and 
young children at different socioeconomic groups in Istanbul Blood 2001; 18:19-25.

4. Herbert V. Anemias. Dalam: Paige DM, penyunting. Clinical nutrition. Edisi kedua. Toronto: Mosby,1988. h. 593607.

5. Schultink WS, Gross R, Gliwitzki, Karyadi D, Matulessi P. Effect of daily vs twice weekly iron suplementation in Indonesian preschool children with low iron status. Am J Clin Nutr 1995; 61:111-15.

6. Dalman PR. Iron deficiency and related nutritional anemias. Dalam: Oski FA, Nathan GD, penyunting. Hematology of infancy and childhood. Edisi ketiga. Philadelphia: Saunders, 1987. h. 274-300.

7. Will AM. Iron metabolism, sideroblastic anemia and iron overload. Dalam: Lilleyman JS, Hann IM, Blanchette VS, penyunting. Pediatric hematology. Edisi kedua. New York: Churchill Livingstone, 2000. h. 105-12.

8. Kresno SB. Pengantar hematologi dan imunohematologi. Jakarta: FKUI,1988. h. 37-40.

9. Oski FA. Nutritional anemias of premature and full-term infant. Dalam: Lebenthal E, penyunting. Textbook of gastroenterology and nutrition in infancy. Edisi kedua. New York: Raven, 1989. h. 613-20.

10. Dallman PR. Nutritional anemias in childhood. Iron, folate, and vitamin B 12. Dalam: Suskind RM, Suskin LL, penyunting. Textbook of pediatric nutrition. Edisi kedua. New York: Raven, 1993. h. 91-9.

11. Schwartz E. Anemias of in adequate production. Dalam: Behrman RE, Kliegman RM, Arvin AM, penyunting. Nelson textbook of pediatrics. Edisi kelima belas. Philadelphia: Saunders, 1996. h. 1387-89.

12. Gibson RS. Principles of nutritional assesment. New York: Oxford University, 1990. h. 349-76.

13. Oski FA. Iron deficiency in infancy and childhood. N Engl J Med 1993; 329:190-3.

14. Booth IW, Auket MA. Iron deficiency anaemia in infancy and early childhood. Arch Dis Child 1997; 76:54954.

15. Lozoff $\mathrm{B} \mathrm{dkk}$,. Iron deficiency anemia and therapy effects on infant developmental test performance. Pediatrics 1987; 79:981-95.

16. Nokes C, Bosch C, Bundy DAP. The effects of iron deficiency anemia on mental and motor performance, educational achievement and behavior in children: An annotated bibliography. Didapat dari; URL: http:// www.aii.ilsi.org/file/ACF179.pdf.
17. Connor JR, Benkovic SA. Iron regulation in the brain: Histochemical, biochemical, and molecular consideration. Ann Neurol 1992; 32:S51-S61.

18. Ungria M, Rao R, Wobken JD, LucianaM, Nelson CA, Georgieff. Perinatal iron deficiency decreases cytochrome c oxidase (CytOx) activity in selected regions of neonatal rat brain. Pediatr Res 2000; 48:169-76.

19. Oski FA, Honig AS. The effects of therapy on developmental score of iron deficient infant. J Pediatr 1978; 92:21-5.

20. Soedjatmiko. Stimulasi psikososial pada bayi risiko tinggi. Trihono PT, dkk. Penyunting Hot topic in pediatrics II. Pendidikan kedokteran berkelanjutan Ilmu Kesehatan Anak XLV. Jakarta: FKUI, 2002. h. 28-46.

21. Roncagliolo M, Garrido M, Walter T, Peirano D, Lozoff B. Evidence of altered central nervous System development in infants with iron deficiency anemia at $6 \mathrm{mo}$ : delayed maturation of auditory brainstem responses. Am J Clin Nutr 1998; 68:683-90.

22. Yu GS, Steinkirchner TM, Rao GA, Larkin EC. Effect of prenatal iron deficiency on myelination in rat pups. Am J Pathol 1986; 125:620-4. Dikutip dari: McGregor SG, Ani C. A riview of studies on effect of iron defisiency on cognitive development in children. J Nutr 2001; 131:649S-68S.

23. McGregor SG, Ani C. A riview of studies on the effect of iron deficiency on cognitive development in children. J Nutr 2001; 131:649S-68S.

24. Soemantri AG. Hubungan anemi kekurangan zat besi dengan konsentrasi dan prestasi belajar. Tesis. Semarang: FK. Universitas Diponegoro, 1978.

25. Atkinson RL, Atkinson RC, Hilgard ER. Pengantar psikologi. Edisi ke delapan. Taufiq N, Barhana R, alih bahasa. Dharma A, Adryanto M, penyunting. Jakarta: Penerbit Erlangga, 1999. h. 7-11.

26. Walter T, Kovalsky J, Stekel A. Effect of mild iron deficiency on infant mental development scores. J Pediatr 1985; 102:519-22.

27. Aukett MA, Parks YA, Scott PH, Wharm BA. Treatment with iron increases weight gain and psychomotor development. Arch Dis Child 1986; 61:849-57.

28. Lozoff B, Wolf AW, Jimenes E. Iron-deficiency anemia and infant development: Effects of extended oral iron therapy. J Pediatr 1996; 129:382-9.

29. Idjradinata P, Pollitt E. Reversal of developmental delays in iron-deficient anemic infants treated with iron. Lancet 1993; 341:1-4. 